\title{
JRAK
}

JURNAL RISET

AKUNTANSI

VOLUME 6 NO 2

JULI 2020

DAN BISNIS

jrak@plb.ac.id

\section{MODEL PENGELOLAAN DANA DESA MELALUI PRINSIP AKUNTABILITAS PUBLIK DAN TRANSPARANSI DI KABUPATEN BANDUNG}

Lilis Saidah Napisah dan Cecep Taufiqurachman - STIE Ekuitas Bandung

\begin{abstract}
ABSTRAK
Penelitian ini bertujuan untuk mengetahui pengaruh akuntabilitas publik dan transparansi terhadap pengelolaan dana desa. Akuntabilitas publik dan transparansi merupakan independen serta pengelolaan dana desa merupakan variable dependen. Metode yang digunakan dalam penelitian ini deskriptif dan verifikatif. Data yang digunakan adalah data primer, data diperoleh dari penyebaran kuesioner pada perangkat desa dan masyarakat desa. Sampel penelitian ini menggunakan sampel jenuh. Metode analisis yang digunakan adalah analisis regresi linear berganda dengan program yang digunakan menggunakan SPSS 23.00. Hasil penelitian menunjukan bahwa secara parsial akuntabilitas publik berpengaruh signifikan terhadap pengelolaan dana desa, dan transparansi berpengaruh signifikan terhadap pengelolaan dana desa. Secara simultan akuntabilitas publik dan transparansi berpengaruh secara signifikan positif terhadap pengelolaan keuangan sebesar 38,3\% sedangkan sisanya $61,7 \%$ dipengaruhi variable lain yang tidak diteliti dalam penelitian ini.
\end{abstract}

Kata kunci : Akuntabilitas Publik, Transparansi, Pengelolaan Dana Desa

\section{PENDAHULUAN}

\section{Latar Belakang}

Pengelolaan dana desa dilaksanakan berdasarkan Peraturan Menteri Dalam Negeri RI No.

37 Tahun 2007 pasal 4 ayat 7 tentang Pedoman Pengelolaan Keuangan Daerah, pengelolaan dana desa yang baik membutuhkan Akuntabilitas dan Tranparansi agar dapat sesuai dengan kebijakan yang berlaku. Diperkuat juga dengan Undang-Undang Nomor 32 Tahun 2004 tentang Pemerintah Daerah, untuk mewujudkan akuntabilitas dan transparansi pengelolaan keuangan pemerintah baik pusat maupun daerah adalah dengan menyampaikan informasi laporan pertanggungjawaban berupa laporan keuangan. Laporan Keuangan tersebut diharapkan dapat dikelola dengan baik, transparan, ekonomis, efisien, efektif dan akuntabel. Petunjuk teknis penggunaan dana desa tahun 2018 yaitu untuk padat karya tunai, dimna penggunaan dana desa dapat difokuskan pada pekerjaan yang menyerap banyak tenaga kerja untuk mengurangi angka pengangguran di desa. Adapun sasaran utama dari program Padat Karya Tunai ini adalah 
masyarakat yang masuk kategori menganggur, setengah menganggur (bekerja kurang dari 35 jam seminggu), penduduk miskin, penerima Program Keluarga Harapan, dan penduduk dengan balita bermasalah gizi (stunting). Maka dari itu di perlukan pengelolaan yang sangat tepat agar terlaksana dengan baik.

Menurut Setiana dan Yuliani (2017:206) akuntabilitas adalah kewajiban pemegang amanah/agent/kepala desa dan aparatnya untuk memberikan pertanggungjawaban, menyajikan, melaporkan dan mengungkapkan segala aktivitas dan kegiatan yang menjadi tanggung jawab kepada pihak pemberi amanah (principal) yang memiliki hak dan kewenangan untuk pertangunggjawaban tersebut. Menurut Poae dan Saerang (2013:29) akuntabilitas mengandung arti pertanggungjawaban, baik oleh orang-orang maupun badan-badan yang dipilih, atas pilihanpilihannya dan tindakannya.

Menurut Setiana dan Yuliani (2017:206) transaparansi adalah memberikan informasi keuangan yang terbuka dan jujur pada masyarakat berdasarkan pertimbangan bahwa masyarakat memiliki hak untuk mengetahui secara terbuka dan menyeluruh atas pertanggungjawaban pemerintah dalam pengelolaaan sumber daya yang dipercayakan kepadanya dan ketaatannya pada peraturan perundang-undangan. Menurut Poae dan Saerang (2013:29) transparan merupakan suatu kebebasan mengakses aktivitas politik dan ekonomi pemerintah dan keputusankeputusannya.

Menurut Wisnawati,dkk (2018) Pengelolaan Dana Desa harus berdasarkan pada prinsipprinsip pelaksanaan yang transparan dan terbuka, peran aktif masyarakat mulai dari proses perencanaa, pelaksanaan, pengawasan dan pemeliharaan, pelakasanaan kegiatan yang dapat di pertanggungjawabkan secara admininstratif, teknis dan hukum, peningkatan fungsi peran lembaga kemasyarakatan, dan pelestarian kegiatan yang dikembangkan secara berkelanjutan melalui partisipasi masyarakat. Penggunaan Dana Desa dibagi menjadi dua bagian, yaiutu untuk penyelenggaraan Pemerintah Desa sebesar 30\% dan sebesar $70 \%$ untuk pemberdayaan masyarakat desa.

Pengelolaan Dana Desa yang baik sangat penting bagi kelangsungan dan perkembangan organisasi karena erat kaitannya dengan kelangsungan kesejahteraan masyarakat luas khususnya masyarakat yang berada di daerah pedesaan. Penting bagi aparatur Desa untuk mengelola dana desa sesuai yang akuntabel dan trasparan terhadap kebijakan yang berlaku agar tercapaikan semua tujuan. Dari permasalahan yang ada dan latar belakang diatas yang dihadapi oleh pemerintah desa dalam pengelolaan dana desa tersebut, maka peneliti tertarik untuk melakukan penelitian dengan judul " Model Pengelolaan Dana Desa Melalui Prinsip Akuntabilitas Publik Dan Transparansi Di Kabupaten Bandung".

\section{Tujuan Penelitian}

Tujuan yang ingin dicapai dalam kegiatan penelitian ini adalah:

Untuk mengetahui Model Pengelolaan Dana Desa, prinsip Akuntabilitas Transparansi di

Kabupaten Bandung dan pengaruh prinsip Akuntabilitas Publik dan Transparansi terhadap Pengelolaan Dana Desa di Kabupaten Bandung.

\section{Road Map Penelitian}

Road Map penelitian ini mengacu pada Road Map Topik Riset dan Sub Topik Riset Bidang 
Unggulan STIE Ekuitas pada Topik Akuntansi Keuangan dan Sub Topik Implementasi Akuntansi Keuangan, terlihat pada gambar dibawah ini :

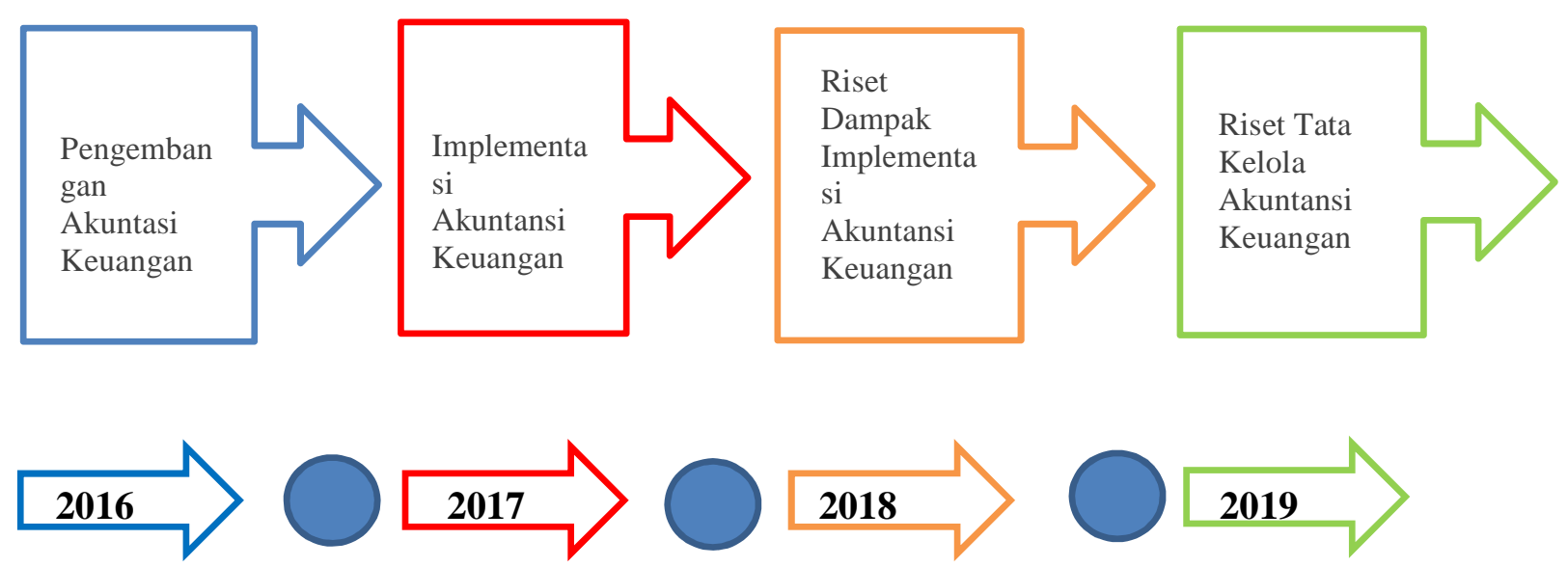

\section{LANDASAN TEORI}

\section{Akuntabilitas Publik}

Menurut Bastian (2010:385) Akuntabilitas Publik adalah sebagai berikut :

"Akuntabilitas Publik adalah kewajiban untuk menyampaikan pertanggungjawaban atau untuk menjawab, menerangkan kinerja, dan tindakan seseorang atau badan hukum dan pimpinan kolektif atau organisasi kepada pihak yang memiliki hak atau berkewenangna untuk meminta keterangan atau pertanggungjawaban."

Menurut Mardiasmo dalam Yunita dan Chirtianingrum (2018: 100) adalah sebagai berikut: " Akuntabilitas Publik adalah kewajiban pemegang kepercayaan untuk memberikan pertanggungjawaban, menyajikan dan mengungkapkan semua kegiatan dan kegiatannya yang merupakan tanggung jawabnya kepada prinsip yang memiliki hak dan wewenang untuk menerima pertanggungjawaban."

Menurut Setiana dan Yuliani (2017:206) menyatakan bahwa Akuntabilitas adalah: "Akuntabilitas adalah kewajiban pemegang amanah/agent/kepala desa dan aparatnya untuk memberikan pertanggungjawaban, menyajikan, melaporkan dan mengungkapkan segala aktivitas dan kegiatan yang menjadi tanggung jawab kepada pihak pemberi amanah (principal) yang memiliki hak dan kewenangan untuk pertangunggjawaban tersebut."

Menurut Program Pembangunan Perserikatan Bangsa-Bangsa, dalam Yunita dan Chirtianingrum (2018:101) menyebutkan bahwa prinsip yang terdapat dalam akuntabilitas yaitu:

1. Transparansi, berkaitan mengenai kemampuan organisasi mengngungkapkan fakta mengenai kinerjanya.

2. Kewajiban, berkaitan mengenai cara organisasi menangani konsekuensi dari kinerjanya.

3. Dapat dikendalikan, berkaitan dengan mengenai penyelesaian tugas yang telah diberikan.

4. Tanggung jawab, berkaitan mengenai tanggung jawab atas standar kinerja yang ada.

5. Tanggapan, berkaitan mengenai pemenuhan harapan nyata pemangku kepentimngan yang harus dipenuhi organisasi. 
Menurut Yunita dan Chirtianingrum (2018:101-103) pertama, Transparansi merupakan bagian integral dari prinsip akuntabilitas. Berdasarkan prinsip transparansi, indikator desa yang menerima dana desa telah menerapkan prinsip ini apakah organisasi yang bersangkutan mampu menyajikan fakta tentang kinerjanya. Desa yang menerima Program Dana Desa telah dapat menyajikan fakta tentang kinerjanya. Hal ini ditunjukkan oleh laporan realisasi dan laporan pertanggungjawaban tentang realisasi Anggaran Pendapatan dan Belanja (APB Desa) yang telah diinformasikan kepada publik secara tertulis dan dengan media yang mudah diakses oleh publik, misalnya melalui papan buletin. Kedua, berdasarkan prinsip pertanggungjawaban, indikator desa yang menerima dana desa telah menerapkan prinsip ini adalah apakah organisasi yang bersangkutan menghadapi konsekuensi dari kinerjanya.

Penyalahgunaan manajemen keuangan desa adalah tindakan yang dilarang oleh aparat desa. Jika dilakukan maka yang bersangkutan dapat dikenai sanksi administratif dalam bentuk peringatan lisan/tertulis, pemecatan sementara bahkan dapat dilanjutkan dengan pemutusan hubungan kerja. Selain itu, tindakan tersebut jika memenuhi syarat penyalahgunaan keuangan negara yang mengakibatkan kerugian negara, dapat dikategorikan sebagai tindakan korupsi sebagaimana diatur oleh UU No. 31 tahun 1999 sebagaimana telah diubah menjadi UU No. 20 Tahun 2001 tentang Pemberantasan Korupsi. Masyarakat dapat membuat laporan atau pengaduan kepada Badan Konsultasi Desa (BPD) dan Pemerintah Desa, mengenai objek kegiatan dan estimasi nilai kerugian yang disalahgunakan. Dalam pelaporan atau pengaduan, perlu disertai penjelasan konkret tentang obyek kegiatan yang menjadi dugaan tindakan penyalahgunaan. Ketiga, berdasarkan prinsip pengendalian, indikator desa yang menerima dana desa telah menerapkan prinsip ini adalah apakah organisasi yang bersangkutan melakukan apa yang diinginkan pihak yang ditugaskan.

Pengawasan pengelolaan keuangan pelaksanaan program dana desa sudah cukup efektif karena telah dilakukan pengawasan langsung terhadap inspektorat dan BPK. Namun fungsi kontrol yang dilakukan oleh masyarakat belum dikelola dengan baik. Mekanisme pengaduan masyarakat harus diserahkan secara tertulis kepada Kepala Desa. Keempat, berdasarkan prinsip tanggung jawab, indikator desa yang menerima dana desa telah menerapkan prinsip ini adalah apakah organisasi yang bersangkutan memiliki tanggung jawab atas standar kinerja yang ada. Kewajiban aparat desa dalam pertanggungjawaban laporan realisasi program dana desa meliputi laporan pendapatan, pengeluaran dan pembiayaan. Format pelaporan telah disesuaikan dengan format yang ditetapkan dalam Permendagri No. 113 Realisasi APBDesa 2014. Format laporan pertanggungjawaban untuk realisasi pelaksanaan APBDesa telah melampirkan Laporan Pertanggungjawaban tentang Realisasi Implementasi APBDeskripsi mengenai fiskal terkait. Kelima, berdasarkan prinsip daya tanggap, indikator desa yang menerima dana desa telah menerapkan prinsip ini adalah apakah organisasi yang bersangkutan telah memenuhi harapan nyata para pemangku kepentingan. Sejauh ini belum ada penyimpangan dari pengelolaan dana desa. Untuk pelaksanaan program dana desa, aparat desa telah berkoordinasi dengan masyarakat melalui Dewan Konsultasi Desa dalam perencanaan dan penganggaran dalam pelaksanaan program dana desa.

\section{Transparansi}

Menurut Nordiawan (2009:36) menyatakan bahwa definisi dari transparansi adalah sebagai berikut: "Transparansi adalah memberikan informasi keuangan yang terbuka dan jujur 
kepada masyarakat berdasarkan pertimbangan bahwa masyarakat memiliki hak untuk mengetahui secara terbuka dan menyeluruh atas pertanggungjawaban pemerintah dalam pengelolaan sumber daya yang dipercayakan kepadanya dan ketaaatannya pada peraturan perundang-undang."

Menurut Pasal 4, paragraf 7 Peraturan Menteri Dalam Negeri Republik Indonesia No. 13, 2006 tentang Pedoman Pengelolaan Keuangan Daerah, menyatakan bahwa "Transparansi adalah prinsip keterbukaan yang memungkinkan masyarakat untuk mengetahui dan memiliki akses ke informasi sebanyak mungkin tentang keuangan daerah."

Menurut Setiana dan Yuliani (2017:206) trasparansi adalah memberikan informasi keuangan yang terbuka dan jujur pada masyarakat berdasarkan pertimbangan bahwa masyarakat memiliki hak untuk mengetahui secara terbuka dan menyeluruh atas pertanggungjawaban pemerintah dalam pengelolaaan sumber daya yang dipercayakan kepadanya dan ketaatannya pada peraturan perundang-undangan."

Transparansi artinya dalam menjalankan pemerintahan, pemerintah mengungkapkan halhal yang sifatnya material secara berkala kepada pihak-pihak yang memiliki kepentingan, dalam hal yaitu masyarakat luas sehingga prinsip keterbukaan yang memungkinkan masyarakat mengetahui dan mendapatkan akses informasi seluas-luasnya tentang keyangan daerah. Menurut Krina dalam Hanifah dan Praptoyo (2015:7) mengatakan bahwa prinsip- prinsip transparansi dapat diukur melaluli sejumlah indikator berikut:

1. Mekanisme yang menjamin sistem keterbukaan dan standarisasi dari semua proses-proses pelayanan publik;

2. Mekanisme yang memfasilitasi pertanyaan-pertanyaan publik tentang kebijakan dan pelayanan publik, maupun proses-proses didalam sector publik;

3. Mekanisme yang memfasilitasi pelaporan maupun penyebaran isformasi maupun penyimpangan tindakan apparat publik di dalam kegiatan melayani.

Sedangkan indikator- indikator prinsip transparansi menurut Kristianten dalam Ultafiah (2017:25) adalah sebagai berikut:

1. Penyediaan dan akses informasi yang jelas tentang perencanaan, prosedur pelaksanaan dan pertanggungjawaban;

2. Adanya musyawarah yang melibatkan masyarakat;

3. Keterbukaan proses pengelolaan;

4. Keterbukaan informasi tentang dokumen pengelolaan Dana Desa.

Beberapa manfaat yang didapat jika transparansi ini dilaksanakan, antara lain menurut Jamaludin (2015:6):

1. Menciptakan horizontal accountability antara pemerintah Desa dengan penduduk Desa dan pihak-pihak lain sehingga tercipta pemerintahan yang transparan, efisien, efektif dan responsif terhadap aspirasi dan kepentingan masyarakat Desa.

2. Menciptakan hubungan harmonis antara pemerintah Desa dengan masyarakat Desa dalam mendukung pengambilan keputusan yang ekonomis untuk kepentingan pemberdayaan masyarakat dan pembangunan Desa.

3. Membandingkan kinerja anggaran / penggunaan anggaran dan untuk menilai kondisi dana dengan hasil yang dicapai, sehingga berguna untuk menyusun prioritas anggaran untuk mewujudkan program yang diprioritaskan.

4. Sebagai kontrol publik terhadap pemerintah Desa 


\section{Pengelolaan Dana Desa}

Dalam pengelolaan dana Desa menuerut Peraturan Menteri Dalam Negeri nomor 113 tahun 2014 menyebutkan bahwa pengelolaan merupakan keseliruhan kegiatan yang meliputi perencanaa, pelaksanaan, penatausahaan, pelaporan dan pertanggungjawaban keuangan desa. Hal tersebut dapat dijelaskan sebagai berikut ini:
1. Perencanaan
2. Pelaksanaan
3. Penatausahaan
4. Pelaporan
Pertanggungjawaban.

\section{METODOLOGI PENELITIAN}

\section{Operasional Variabel Penelitian}

Adapun variabel-variabel yang terkait dalam penelitian ini adalah:

1. Variabel Bebas/Independent (X)

Menurut Sekaran (2017:79) variabel bebas adalah variabel yang memengaruhi variabel terikat, baik secara positif atau negatif. Dalam hubungannya dengan judul yang ditetapkan yang menjadi variabel bebas adalah Akuntabilitas dan Transparansi

2. Variabel Terikat/Dependent (Y)

Menurut Sekaran (2017:77) variabel terikat merupakan variabel yang menjadi perhatian peneliti. Dengan kata lain, variabel terikat merupakan variabel utama yang menjadi faktor yang berlaku dalam investigasi. Variabel terikat dalam penelitian ini adalah Pengelolaan Dana Desa.

Tabel 1 Operasional Variabel Penelitian

\begin{tabular}{|c|c|c|c|}
\hline Variabel & Definisi Variabel & Indikator & Skala \\
\hline $\begin{array}{l}\text { Akuntabilas } \\
\text { Publik }\left(\mathrm{X}_{1}\right)\end{array}$ & $\begin{array}{l}\text { Akuntabilitas Publik adalah kewajiban } \\
\text { untuk menyampaikan } \\
\text { pertanggungjawaban atau untuk } \\
\text { menjawab, menerangkan kinerja, dan } \\
\text { tindakan seseorang atau badan hukum } \\
\text { dan pimpinan kolektif atau organisasi } \\
\text { kepada pihak yang memiliki hak atau } \\
\text { berkewenangna untuk meminta } \\
\text { keterangan atau pertanggungjawaban. } \\
\text { Bastian (2010:385) }\end{array}$ & $\begin{array}{ll}\text { 1. } & \text { Akuntabilitas } \\
\text { Kejujuran dan Hukum } \\
\text { 2. Akuntabilitas } \\
\text { Manajerial } \\
\text { 3. Akuntabilitas } \\
\text { Program } \\
\text { 4. Akuntabilitas } \\
\text { Kebijakan } \\
\text { 5. Akuntabilitas Fiansial } \\
\text { Mardiasmo ( 2009) }\end{array}$ & Ordinal \\
\hline $\begin{array}{l}\text { Transparansi } \\
\left(\mathrm{X}_{2}\right)\end{array}$ & $\begin{array}{l}\text { Transparansi adalah prinsip } \\
\text { keterbukaan yang memungkinkan } \\
\text { masyarakat untuk mengetahui dan } \\
\text { memiliki akses ke informasi sebanyak } \\
\text { mungkin tentang keuangan daerah. } \\
\text { Peraturan Menteri Dalam Negeri } \\
\text { Republik Indonesia nomor 13/PPKD/ }\end{array}$ & $\begin{array}{l}\text { 1. Informasi } \\
\text { 2. Keterbukaan } \\
\text { 3. Pengungkapan } \\
\text { Mahmudi (2015) }\end{array}$ & Ordinal \\
\hline
\end{tabular}




\begin{tabular}{|c|c|c|c|}
\hline Variabel & Definisi Variabel & Indikator & Skala \\
\hline & 2006 & & \\
\hline $\begin{array}{l}\text { Pengelolaan } \\
\text { Dana Desa (Y) }\end{array}$ & $\begin{array}{l}\text { pengelolaan keuangan desa adalah } \\
\text { semua kegiatan yang meliputi } \\
\text { perencanaan, pelaksanaan, } \\
\text { administrasi, pelaporan desa dan } \\
\text { akuntabilitas keuangan. Dalam } \\
\text { pengelolaan dana desa, diperlukan } \\
\text { untuk mengawasi awal transparansi } \\
\text { mereka dan untuk memastikan apakah } \\
\text { pemerintah desa telah melaksanakan } \\
\text { mandat masyarakat dalam penggunaan } \\
\text { dana desa dan apakah pengelolaan } \\
\text { dana desa dilakukan oleh pemerintah } \\
\text { sesuai dengan kebutuhan penduduk } \\
\text { desa atau dalam hal ini sesuai dengan } \\
\text { keputusan perencanaan desa dan } \\
\text { musyawarah pembangunan } \\
\text { (selanjutnya disebut Musrenbangdes). } \\
\text { Peraturan Menteri Dalam Negeri No } \\
\text { 113 tahun } 2014\end{array}$ & $\begin{array}{l}\text { 1. Tahap Perencanaan } \\
\text { 2. Tahap Pelaksanaan } \\
\text { 3. Tahap Pelaporan } \\
\text { 4. Tahap } \\
\quad \text { Pertanggungjawaban } \\
\text { Peraturan Menteri Dalam } \\
\text { Negeri } \\
\text { No. } 113 \text { tahun } 2014\end{array}$ & Ordinal \\
\hline
\end{tabular}

\section{PEMBAHASAN}

\section{Kondisi Pengelolaan Dana Desa Pada Desa di Kecamatan Cimenyan Kabupaten Bandung}

Berdasarkan hasil pengujian yang telah dilakukan terhadap variabel Pengelolaan Dana Desa pada tabel 4.9 diperoleh hasil "sangat tinggi". Hal tersebut dibuktikan dengan jawaban responden atas variabel Pengelolaan Dana Desa (Y) yang didominasi jawaban "sangat setuju" sehingga diperoleh total skor sebesar 2.542 dengan prosentase 90,14\%, maka diperoleh kesimpulan bahwa Pengelolaan Dana Desa dikategorikan "sangat tinggi". Hal ini berarti pengelolaan dana desa yang dilakukan oleh Aparatur Desa dan diketahui masyarakat desa telah diterapkan dengan baik. Pengelolaan dana desa terdiri dari 5 indikator yaitu Perencanaan, Pelaksanaan, Penatausahaan, Pelaporan dan Pertanggungjawaban diukur dengan 12 pernyataan. Pada jawaban responden mengenai variable pengelolaan dana desa untuk yang menjawab sangat setuju sebesar 51,42\% dan yang menjawab setuju sebesar 48,57\%. Dapat diartikan bahwa semua desa yang ada pada Kecamatan Cimenyan memang sudah melakukan pengelolaan sesuai dengan kebikan yang berlaku dengan baik dan mempunyai pemahan mengenai undang-undang yang mengatur mengenai pengelolaan dana desa tersebut.

\section{Pengaruh Akuntabilitas Publik dan Transparansi terhadap pengelolaan Dana Desa pada Desa di Kecamatan Cimenyan Kabupaten Bandung.}

Berdasarkan hasil pengujian output regresi uji $\mathrm{F}$ secara simultan pada tabel 4.26 menunjukan bahwa angka signifikansi sebesar 0,000. Nilai tersebut lebih kecil dari tingkat signifikansi $\alpha=0,05(0,000<0,005)$. Hipotesis ke 4 yang menyatakan akuntabilitas publik dan transparansi berpengaruh terhadap pengelolaan dana desa diterima, sehingga dapat disimpulkan 
bahwa akuntabilitas publik dan transparansi berpengaruh secara simultan terhadap pengelolaan dana desa.

Dalam analisis deskriptif menunjukkan bahwa pada desa di Kecamatan Cimenyan Kabupaten Bandung sudah menerapkan Akuntabilitas Publikn dengan baik, hal ini ditunjukkan dengan adanya pertanggungjawaban setiap tugas dan wewenang dengan mendapatkan proporsi sebesar 89,59\%. Selain itu desa di Kecamatan Cimenyan Kabupaten Bandung menerapkan Transparansi dengan baik, hal ini ditunjukkan dengan adanya keterbukaan informasi yang semestinya harus diketahui dengan mendapatkan proporsi sebesar 92,34\%. Serta desa di Kecamatan Cimenyan Kabupaten Bandung pun telah melakukan pengelolaan dana desa dengan baik, hal ini ditunjukkan dengan adanya kesesuaian pengelolaan yang berpedoman pada undangundang dengan mendapatkan proporsi sebesar 90,14\%.

\section{KESIMPULAN DAN SARAN}

\section{Kesimpulan}

Berdasarkan hasil penelitian mengenai Akuntabilitas Publik dan Transparansi terhadap Pengelolaan Dana Desa, dapat disimpulkan bahwa:

1. Berdasarkan hasil pembahasan akuntabilitas publik desa di Kecamatan Cimenyan Kabupaten Bandung dari hasil penggujian mendapatkan persentase sebesar 89,89\%. Hal tersebut menunjukan bahwa akuntabilitas publik yang ada pada desa di Kecamatan Cimenyan Kabupaten Bandung telah berjalan dengan baik dan sesuai dengan apa yang telah dilakukan.

2. Berdasarkan hasil pembahasan transparansi desa di Kecamatan Cimenyan Kabupaten Bandung mendapatkan persentase sebesar $85,31 \%$. Hal tersebut menunjukan bahwa keterbukaan atau transparansi telah berjalan dengan sangat baik.

3. Berdasarkan hasil pembahasan pengelolaan dana desa, pada desa di Kecamatan Cimenyan Kabupaten Bandung dari hasil penggujian mendapatkan persentase sebesar 90,14\%. Hal tersebut menunjukan bahwa pengelolaan dana desa yang ada pada desa di Kecamatan Cimenyan Kabupaten Bandung telah berjalan dengan sangat baik.

4. Akuntabilitas publik dan trasparansi secara simultan berpengaruh positif terhadap pengelolaan dana desa. Maka dapat diartikan bahwa peningkatan akuntabilitas publik dan transparansi akan meningkatkan pengelolaan dana desa secara baik.

\section{Saran}

Saran yang diajukan penulis dari penelitian yang telah dilakukan antaralain:

a. Akuntabilitas publik pada desa di Kecamatan Cimenyan Kabupaten Bandung, berdasarkan tanggapan responden masih ada kelemahan didalam yang tidak berjalan sesuai dengan semestinya. Diharapkan perangkat desa dan masyarakat berperan aktif dalam proses pertanggungjawaban.

b. Transparansi pada desa di Kecamatan Cimenyan Kabupaten Bandung sebaiknya, memasang billboard atau menyedisksn informasi yang dapat diakses dan dilihat oleh pihak yang berkepentingan mengenai desa. Dalam melakukan pemasangan billboard atau media lainnya yang menunjang transparansi lebih baik dilakukan pada tempat-tempat yang strategis dan diperbanyak. 
c. Pengelolaan dana desa pada Kecamatan Cimenyan Kabupaten Bandung perlu ditingkatkan lagi, terutama dengan keseuaian pengelolaan dilaksanakan berdasarkan Peraturan Menteri Dalam Negeri RI No. 37 Tahun 2007 pasal 4 ayat 7 tentang Pedoman Pengelolaan Keuangan Daerah. Dengan cara meningkatkan akuntabilitas publik dan transparansi terhadap pengelolaan dana desa.

\section{DAFTAR PUSTAKA}

Bastian, I. (2010). Akuntansi Sektor Publik Satu Pengantar. Edisi Ketiga. Jakarta: Erlangga.

Ghozali, I. (2016), Aplikasi Analisis Multivariete Dengan Program IBM SPSS 23 (Edisi 8). Semarang: Badan Penerbit Universitas Diponegoro.

Hanifah dan Praptoyo. (2015). Akuntabilitas dan Transparansi Pertanggungjawaban Anggaran Pendapatan Belanja Desa (APBDes). Jurnal Sekolah Tinggi Ilmu Ekonomi Indosesia (STIESIA) Surabaya, Vol. 4 No. 8, hal 7.

https://www.pikiran-rakyat.com/bandung-raya/2017/06/06/laporan-diperketat-danadesa-di-bandung-barat-belum-disalurkan-402572 diunduh pada 28 Januari 2019

https://www.republika.co.id/berita/ekonomi/makro/17/05/15/oq0040416-ratusan-desadi-kabupaten-bandung-belum-laporkan-penggunaan-dana-desa diunduh pada 28 Januari 2019

https://www.kemenkeu.go.id/apbn2018 diunduh pada 17 Februari 2019

http://www.djpk.kemenkeu.go.id/?p=6400 diunduh pada 28 Januri 2019

https://odesa.id/tag/cimenyan/diunduh pada 21 Mei 2019

https://bandungkab.bps.go.id/publication/2018/08/16/6a9ca3559cc9fea40692elae/kabup aten-bandung-dalam-angka-2018.html diunduh pada 28 Januari 2019

https://bandungkab.bps.go.id/publication/2018/09/26/a2187515c1f0cc29eb05adca/keca matan-cimenyan-dalam-angka-2018.html diunduh pada 29 Januari 2019

https://www.kemenkeu.go.id/media/6749/buku-pintar-dana-desa.pdf diunduh pada 30 September 2018

https://www. jabarekspres.com diunduh pada 05 Juli 2019

Jamaludin Y. (2016). Akuntabilitas Penggunaan Dana Desa Di Indonesia. Jurnal Fakultas FISIP Universitas Islam Sumatera Utara, Vol. 7 No.1, hal 5-12.

Nordiawan, D. (2006). Akuntansi Sektor Publik. Jakarta: Selemba Empat.

Nurrizkiana, dkk. (2017). Determinasi Transparansi dan Akuntabilitas Pengelolaan Keuangan Daerah dan Implikasinya terhadap Kepercayaan Public-Stakeholders. Jurnal Akuntansi dan Investasi Universitas Mataram, NTB Vol. 18 No. 1, hal 28-47.

Nyoman, dkk. (2015). Pengaruh Akuntabilitas, Transparansi, Ketepatan Waktu dan Pengawasan Internal Terhadap Kinerja Anggaran Berkonsep Value For Money Pada Instansi Pemerintah Di Kabupaten Buleleng. E-Journal Fakultas Ekonomi Universitas Pendidikan Ganesha Singaraja, Vol. 3 No. 1, hal 11-12.

Mahmudi. (2015). Manajemen Kinerja Sektor Publik. Edisi Ketiga. Cetakan Pertama. Yogyakarta: UPP STIM YKPN.

Mardiasmo. (2009). Akuntansi Sektor Publik. Yogyakarta: Penerbit ANDI. 
Peraturan Menteri Dalam Negeri Republik Indonesia Nomor 113 Tahun 2014 Tentang Pengelolaan Keuangan Desa.

Peraturan Menteri Dalam Negeri Nomor 13 Tahun 2006 Tentang Pedoman Pengelolaan Keuangan Daerah.

Peraturan Menteri Desa, Pembangunan Daerah Tertinggal, Dan Transmigrasi Republik Indonesia Nomor 19 Tahun 2017 Tentang Penetapan Prioritas Penggunaan Dana Desa Tahun 2018.

Pertiwi, D. (2015). Pengaruh Akuntabilitas, Transparansi dan Pengawasan Terhadap Pengelolaan Anggaran Berkonsep Value For Money Pada Instansi Pemerintah Di SKPD Riau. Jurnal Fakultas Ekonomi Universitas Riau, Vol. 2 No. 2, hal 14.

Poe dan Saerang. (2013). Pengaruh Akuntabilitas dan Aksibilitsnya Terhadap Trasparansi dan Akuntabilitas Pengelolaan Keuangan Daerah Di Pemerintahan kabupaten Kepulauan Talaud. Jurnal Accountability, Vol.2 No. 1, hal 29-34.

Sekaran, U. (2017), Metode Penelitian Untuk Bisnis. Jakarta: Salemba Empat.

Sugiyono. (2017), Metode Penelitian Kuantitatif, Kualitatif, dan R\&D. Bandung: Alfabeta.

Sugiono. (2012), Metode Penelitian Kuantitatif, Kualitatif, dan R\&D. Bandung: Alfabeta.

Setiana dan Yuliani. (2017), Pengaruh Pemahaman dan Perangkat Desa Terhadap Akuntabnilitas Pengelolaan Dana Desa. Jawa Timur. Jurnal Fakultas Ekonomi dan Bisnis Universitas Muhamadiyah, Vol. 1 No. 2, hal 206.

Undang-Undang Republik Indonesia Nomor 6 Tahun 2014 Tentang Desa.

Umami dan Nurodin. (2017). Pengaruh Transparansi dan Akuntabilitas Terhadap Pengelolaan Keuangan Desa. Jurnal Ilmian Ilmu Ekonomi Universitas Muhammadiyah Sukabumi, Vol. 6 No. 11, hal 79.

Ultafiah, W. (2017). Pengaruh Akuntabilitas dan Trasparansi Terhadap Pengelolaan Dana Desa Untuk Mewujudkan Good Governance Pasa Desa Di Kecamatan Merapai Barat, Kabupaten Lahat. Palembang. Jurnal Fakultas Ekonomi dan Bisnis Universitas Muhammadiayah Palembang, Vol. 1 No. 1, hal 25- 9.

Wisnawati, dkk. (20118). Pengaruh Akuntabilitas publik Terhadap Pengelolaan Dana Desa Di Kecamatan Anngeraja kabupaten Enrekang Rappang. Jurnal STISIP Muhammadiyah Rappang, Vol. 4 N0.2, hal 113.

Yunita dan Chirtianingrum. (2018). Measurement of Accountability Management of Village Funds. Jurnal facultas of Economy University of Bangka Belitung, Vol. 2 No. 1, hal 100102. 